\title{
Effects of first- and second-generation bioenergy crops on soil processes and legacy effects on a subsequent crop
}

\author{
MAARTEN SCHRAMA ${ }^{1}$, BART VANDECASTEELE ${ }^{2}$, SABRINA CARVALHO ${ }^{1}$, HILDE \\ MUYLLE ${ }^{2}$ and WIM H. VAN DER PUTTEN ${ }^{1,3}$ \\ ${ }^{1}$ Department of Terrestrial Ecology (NIOO-KNAW), Netherlands Institute for Ecology, Droevendaalsesteeg 10, 6708 PB \\ Wageningen, The Netherlands, ${ }^{2}$ Institute for Agricultural and Fisheries Research (ILVO), Plant Sciences Unit, Caritasstraat 21, \\ 9090 Melle, Belgium, ${ }^{3}$ Laboratory of Nematology, Department of Plant Sciences, Wageningen University (WUR), PO Box 8123, \\ 6700 ES Wageningen, The Netherlands
}

\begin{abstract}
To develop a more sustainable bio-based economy, an increasing amount of carbon for industrial applications and biofuel will be obtained from bioenergy crops. This may result in intensified land use and potential conflicts with other ecosystem services provided by soil, such as control of greenhouse gas emissions, carbon sequestration, and nutrient dynamics. A growing number of studies examine how bioenergy crops influence carbon and nitrogen cycling. Few studies, however, have combined such assessments with analysing both the immediate effects on the provisioning of soil ecosystem services as well as the legacy effects for subsequent crops in the rotation. Here, we present results from field and laboratory experiments on effects of a standard first-generation bioenergy crop (maize) and three different second-generation bioenergy crops (willow short rotation coppice (SRC), Miscanthus $\times$ giganteus, switchgrass) on key soil quality parameters: soil structure, organic matter, biodiversity and growth and disease susceptibility of a major follow-up crop, wheat (Triticum aestivum). We analysed a 6-year field experiment and show that willow SRC, Miscanthus, and maize maintained a high yield over this period. Soil quality parameters and legacy effects of Miscanthus and switchgrass were similar or performed worse than maize. In contrast, willow SRC enhanced soil organic carbon concentration $(0-5 \mathrm{~cm})$, soil fertility, and soil biodiversity in the upper soil layer when compared to maize. In a greenhouse experiment, wheat grown in willow soil had higher biomass production than when grown in maize or Miscanthus soil and exhibited no growth reduction in response to introduction of a soil-borne (Rhizoctonia solani) or a leaf pathogen (Mycosphaerella graminicola). We conclude that the choice of bioenergy crops can greatly influence provisioning of soil ecosystem services and legacy effects in soil. Our results imply that bioenergy crops with specific traits might even enhance ecosystem properties through positive legacy effects.
\end{abstract}

Keywords: life cycle assessment, maize, Miscanthus, short rotation coppice, soil ecosystem services, switchgrass, willow SRC

Received 25 August 2014 and accepted 10 November 2014

\section{Introduction}

There is increasing interest in transition towards a biobased economy to produce food, feed, biofuels, construction materials, and bio-based products for the chemical industry in a more sustainable way (The White House, 2002; European Commission, 2005; Millenium Assessment, 2005). Bioenergy crops play a fundamental role in this transition. Until now, studies on the effects of bioenergy crops have focused primarily on analysing consequences for land use change, greenhouse gas (GHG) emissions, and soil biogeochemistry (Searchinger et al., 2008; Tilman et al., 2009; Djomo et al., 2011; Georgescu et al., 2011). In general, perennial second- or

Correspondence: Maarten Schrama, tel. +44 161275 1484,

e-mail: m.schrama@nioo.knaw.nl third-generation bioenergy crops (such as tall-growing perennial grasses and short rotation woody crops) are considered more favourable for reducing GHG emissions (Scharlemann \& Laurance, 2008). However, consequences on soil biodiversity, the provisioning of soil ecosystem services, and legacy effects on future crops have received far less attention. In this study, we evaluate immediate and lag (or legacy) effects of different bioenergy crops on soil ecosystem services.

During the past decades, intensification of agricultural practices has resulted in degradation of soil biodiversity and soil functioning (De Vries et al., 2012a; Hedlund \& Harris, 2012). A worldwide decrease in soil organic matter content is thought to be one of the principal factors behind these observed changes (Bellamy et al., 2005; De Vries et al., 2012b). Lower soil organic matter content can result in lower water holding 
capacity, cation exchange capacity, soil pathogen suppression, nutrient mineralization, and increased nutrient leaching (Workneh et al., 1993; Van Bruggen, 1995). Because the main purpose of bioenergy crops is to collect as much of the assimilated carbon dioxide as possible for the production of bioenergy and bioproducts, a further reduction in soil organic matter can be expected. Particularly, growing conventional agricultural crops (so-called first-generation bioenergy crops), where larger quantities of organic matter are removed (including crop residues e.g. straw, corn stubbles), may thus lead to a further depletion of the total organic carbon (TOC) pool in soils (Maskina et al., 1993; Lal, 2005). Secondgeneration bioenergy crops have been proposed as alternatives for first-generation bioenergy crops (Lemus \& Lal, 2005; Blanco-Canqui, 2010). Previous studies have demonstrated positive impacts of some second-generation crops on soil organic matter (Frank et al., 2004; Liebig et al., 2008; Rooney et al., 2009; Jandl et al., 2012; Poeplau \& Don, 2014; Zatta et al., 2014), soil structure (Pellegrino et al., 2011), and biodiversity (Pellegrino et al., 2011; Bourke et al., 2014). Absence of tillage and greater litter and root production by these crops may further enhance soil ecosystem services through an increase in the TOC pool in the soil (Six et al., 2000). However, not all studies show positive results of all second-generation bioenergy crops on soil functioning, particularly for soils at high initial soil organic matter (SOM) levels (Omonode \& Vyn, 2006). Overall, the magnitude of benefits of second-generation bioenergy crops appears to depend on soil type, crop species, and management decisions (Blanco-Canqui, 2010). Rigorous comparisons between different first and second-generation crops are therefore needed to identify crops that are most adequate for both producing biomass and maintaining or improving soil functioning.

The specific aims of this study were to compare (1) the direct (immediate) effects of different second-generation bioenergy crops and one first-generation bioenergy crop on the provisioning of soil ecosystem services: biomass production, soil biodiversity, soil structure, and carbon storage, and (2) the indirect (legacy) effects of different bioenergy crops on soil as indicated by biomass production and disease susceptibility of the subsequent food/feed crop wheat (Triticum aestivum) under controlled conditions. We carried out field and laboratory experiments with different second-generation bioenergy crops: willow SRC (Salix fragilis), switchgrass (Panicum virgatum L.), and Miscanthus (Miscanthus $\times$ giganteus), and one standard first-generation bioenergy crop: maize (Zea mays) to test the following hypotheses: (1) second-generation perennial bioenergy crops enhance provisioning soil ecosystem services (TOC, soil biodiversity, $\mathrm{N}$ mineralization) when compared to a standard first-generation bioenergy crop, and (2) wheat grown in soils from second-generation bioenergy crops grows faster and shows greater pathogen suppression than when grown in soil from a standard first-generation bioenergy crop.

\section{Materials and methods}

\section{Field site}

In 2007, a field trial with different first and second-generation bioenergy crops was set up at the Flemish Institute for Agricultural and Fisheries Research (ILVO), Melle, Belgium (50 59', $3^{\circ}$ $46^{\prime}$ ) on a light-sandy loam soil with a low TOC fraction (between 0.65 and $1.25 \%$ OC in the layer $0-30 \mathrm{~cm}$ ). The climate in this region is temperate maritime with mean rainfall of $800 \mathrm{~mm}$ per year and mean temperature of $10.5^{\circ} \mathrm{C}$ for the past 10 years. Prior to the experiment, this field was used for the cultivation of maize, with rye sown as winter catch crop since 2004. In spring 2007, the field was ploughed and before planting, compost was added at a rate of $25 \mathrm{tha}^{-1}$. The total $\mathrm{N}$ deposition at this site (sum of $\mathrm{NH}_{3}-\mathrm{N}, \mathrm{NH}_{4}{ }^{+}-\mathrm{N}, \mathrm{NO}_{2}-\mathrm{N}$, and $\mathrm{NO}_{\mathrm{y}}-\mathrm{N}$ ) was estimated to be $25 \mathrm{~kg} \mathrm{~N}$ per hectare in 2012 (VMM, 2014).

Four commonly used bioenergy crops were included in this experiment; one first-generation crop: maize (Zea mays variety Atletico, henceforth: maize) and three second-generation crops: willow SRC (Salix fragilis cv. Belgian Red), switchgrass (Panicum virgatum cv. Kanlow), and Miscanthus (Miscanthus $\times$ giganteus). Additionally, we used yield data of two related bioenergy crops: Miscanthus sinensis and maize variety '34b49'. To avoid confusion in the text, we wrote all species in full when comparisons with these varieties were made (all references to Fig. 1, Tables 1 and 2). In the remainder of the text, 'maize' represents Z. mays var. Atletico and 'Miscanthus' represents $M . \times$ giganteus. Two other second-generation perennial bioenergy crops that were originally included in this experiment (Phalaris arundinacea, Phragmites australis) strongly decreased in yield after already two growing seasons, so that they could not be included in this study.

The field trial was set up according to a randomized split-plot block design with three replications. Each replicate (block) was divided into three sub-blocks, corresponding to the four cropping systems defined above (Fig. S1). Both maize varieties were sown between the last week of April and the first week of May, with a row distance of $0.75 \mathrm{~m}$ and density of 10 plants $\mathrm{m}^{-2}$. Fertilizers were applied ten days after sowing $\left(90 \mathrm{~kg} \mathrm{~N} \mathrm{ha}^{-1} \mathrm{yr}^{-1}\right.$ as calcium ammonium nitrate, $50 \mathrm{~kg} \mathrm{P}_{2} \mathrm{O}_{5} \mathrm{ha}^{-1} \mathrm{yr}^{-1}$ as triple super phosphate, $150 \mathrm{~kg} \mathrm{~K}_{2} \mathrm{O} \mathrm{ha}^{-1} \mathrm{yr}^{-1}$ as potassium chloride $(40 \%)$ ), which is below the maximum allowed in Flanders for sandy loam soils. Herbicides were applied two days later at a ratio of $21 \mathrm{ha}^{-1}$ Stomp (BASF Crop Protection) and $1.41 \mathrm{ha}^{-1}$ Frontier (BASF Crop Protection). Maize was harvested at a dry matter (DM) content of approximately $30 \%(w / w)$, at the end of September - beginning of October with a three-row maize harvester C2200 (Kemper). Each growing season, maize soil was superficially tilled before sowing.

The sub-blocks of perennial second-generation bioenergy crops were installed in May 2007. The plots size was 
$3.6 \mathrm{~m} \times 7 \mathrm{~m}$ except for willow SRC, for which it was $6 \mathrm{~m} \times 7 \mathrm{~m}$ (Fig. S1). Miscanthus was established by planting rhizomes at a spacing of $0.6 \mathrm{~m}$ within and between rows. Switchgrass was sown at a density of $1.5 \mathrm{~g} \mathrm{~m}^{-2}$ with a spacing of $0.6 \mathrm{~m}$ between rows. This was the only species for which only 4 sub-blocks were present, as a result of a mistake at the onset of the experiment (Fig. S1). Mechanical weed control was applied in early spring 2008. The plots were harvested once a year, with an Agria cutter bar (Möckmühl, Germany), between the last week of February and the first week of March. Willow SRC was installed by cuttings of $15 \mathrm{~cm}$ at a density of two cuttings $\mathrm{m}^{-2}$. The planting scheme consisted of two twin rows (0.75 m apart) with $1.5 \mathrm{~m}$ between each set of twin rows. The within-row spacing was $0.5 \mathrm{~m}$. Shortly after installation mechanical weed control was applied. No mineral fertilizers were applied. No herbicides or pesticides were used on any of the second-generation crops. Willow SRC was harvested twice

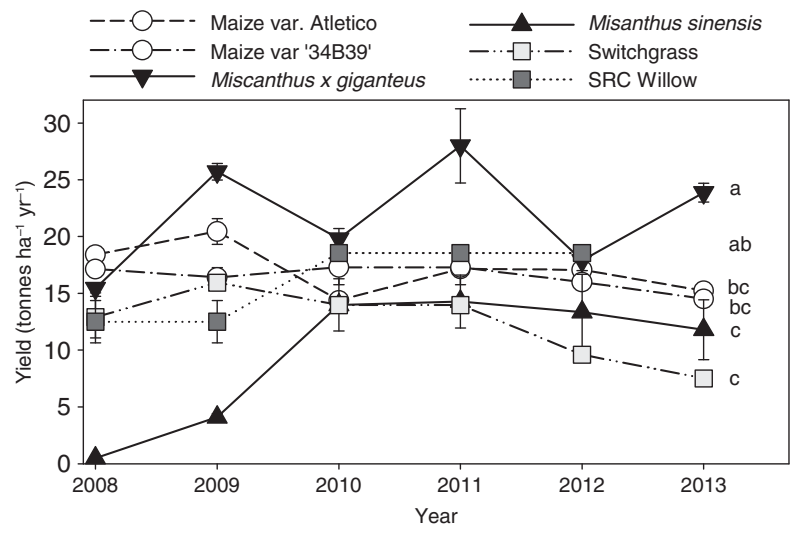

Fig. 1 Mean annual dry matter yield of four bioenergy crops in tonnes $\mathrm{ha}^{-1} \mathrm{yr}^{-1}$. Both maize var. Atletico (open circles) and maize var. $34 b 49$ (open circles) are first-generation bioenergy crops that received an annual dose of mineral fertilizer, while all perennial bioenergy crops (Miscanthus $\times$ giganteus (black triangles), Miscanthus sinensis (black triangles), switchgrass (grey squares) and willow SRC (black squares)) did not receive mineral fertilizer. Willow SRC yields represent averages for 2007-2009 and 2010-2012. Different letters indicate significant differences in yield over period 2010-2012 at $\alpha<0.05$; error bars represent standard errors (SEM). during this experiment, in spring 2010 and 2013, at a height of 5-10 cm above the soil surface. More details on experimental setup can be found in Muylle et al. (2014).

\section{Field sampling}

Crop-specific effect on $C$ and $N$ fluxes. For both maize varieties, willow SRC and both Miscanthus species, data on crop residue biomass and composition were collected in a crop-specific manner. In case of SRC willow, Miscanthus and switchgrass, biomass produced in one year (e.g. 2012) was harvested in the next year (e.g. 2013). Crop yield was determined on an annual basis for all crops. Biomass removal was optimized by reducing the stubble height $(<5 \mathrm{~cm}$ for maize varieties, willow SRC, and Miscanthus species). Annual yield for willow SRC was calculated by dividing yield by three. Roots and stubble of maize were sampled shortly after harvest in 2012. In each block, roots of three individual plants were collected and analysed and averaged for each of the two varieties. For willow SRC, fallen leaves were collected from the three plots between October and December 2012. Leaf fall of both Miscanthus species was collected between January and March 2013. The leaf fall collection for these crops was repeated in the next year with the same methodology. The rhizomes and remaining stubble of one individual plant of Miscanthus per treatment were sampled in April 2012 for each cultivar, that is, 5 years after plant establishment and shortly after harvest. In spring 2013, roots of willow SRC were sampled in each of the three blocks, both within and between rows, in a volume of $1.0 \times 0.5 \times 0.4 \mathrm{~m}$ deep (including two individual trees). Prior to analyses, plant samples were dried at $70^{\circ} \mathrm{C}$ and ground to pass a sieve of $1 \mathrm{~mm}$ in a plant mill (Fritsch pulverisette 19). Plant C was determined by dry combustion at $1050^{\circ} \mathrm{C}$ with a Skalar Primacs SLC TOC-analyzer. $\mathrm{N}$ in harvested maize was measured according to ISO 5983-2 (block digestion/steam distillation method). Total $\mathrm{N}$ in other plant parts was determined with dry combustion (Dumas principle) with a Thermo flash 4000 according to ISO 16634-1. Neutral detergent fibre (NDF), acid detergent fibre (ADF), and acid detergent lignin (ADL) content in the dried compost samples was determined with an Ankom220 Fiber Analyzer extraction unit according to Van Soest et al. (1991). Based on NDF, $\mathrm{ADF}$ and ADL content, the holocellulose/lignin ratio was calculated as (\%hemicellulose $+\%$ cellulose)/(\%lignin), with $\%$ hemicellulose $=\% \mathrm{NDF}-\% \mathrm{ADF}$, and $\%$ cellulose $=\% \mathrm{ADF}-\%$

Table 1 Total C and N stocks in aboveground and belowground crop compartments as measured in the field trial in Melle in the growing season of 2012 for the two varieties of maize, the two species of Miscanthus and willow SRC (third year of the cycle). Data are averages of 3 replicates

\begin{tabular}{|c|c|c|c|c|c|c|c|c|c|}
\hline \multirow[b]{2}{*}{ Crop species } & \multirow{2}{*}{$\begin{array}{l}\text { Fertilization } \\
\mathrm{kg} \mathrm{N} \\
\mathrm{ha}^{-1} \mathrm{yr}^{-1}\end{array}$} & \multicolumn{4}{|c|}{ Total C stocks $\left(\mathrm{kg} \mathrm{C} \mathrm{ha}^{-1}\right)$} & \multicolumn{4}{|c|}{ Total $\mathrm{N}$ stocks $\left(\mathrm{kg} \mathrm{N} \mathrm{ha}^{-1}\right)$} \\
\hline & & Harvested & Leaf fall & $\begin{array}{l}\text { Belowground } \\
+ \text { stubble }\end{array}$ & Total & Harvested & $\begin{array}{l}\text { Leaf } \\
\text { fall }\end{array}$ & $\begin{array}{l}\text { Belowground } \\
+ \text { stubble }\end{array}$ & Total \\
\hline Willow SRC & 0 & 25920 & 1774 & 7288 & 34982 & 250 & 64 & 80 & 394 \\
\hline Miscanthus $\times$ giganteus & 0 & 10793 & 2160 & 1495 & 14447 & 61 & 34 & 35 & 130 \\
\hline Miscanthus sinensis & 0 & 6084 & 1217 & 1765 & 9065 & 50 & 28 & 39 & 117 \\
\hline Maize variety ' $34 B 39$ ' & 90 & 7217 & 0 & 1177 & 8394 & 165 & 0 & 22 & 187 \\
\hline Maize variety Atletico & 90 & 7284 & 0 & 1160 & 8444 & 152 & 0 & 22 & 174 \\
\hline
\end{tabular}


Table 2 Biochemical composition of all bioenergy crops (HC/L, holocellulose/lignin ratio; DM, dry matter, NA, not assessed). Values are averages of three replicates

\begin{tabular}{|c|c|c|c|c|c|c|}
\hline Crop & Part & $\mathrm{C} / \mathrm{N}$ & $\begin{array}{l}\text { Hemicellulose } \\
(\% / \mathrm{DM})\end{array}$ & $\begin{array}{l}\text { cellulose } \\
(\% / D M)\end{array}$ & $\begin{array}{l}\text { lignin } \\
(\% / D M)\end{array}$ & $\begin{array}{l}\mathrm{HC} / \mathrm{L} \\
\text { ratio }\end{array}$ \\
\hline Willow SRC & Leaf fall, leaves & 25.5 & 16.1 & 16.0 & 27.2 & 1.2 \\
\hline Willow SRC & Leaf fall, branches & 61.9 & 13.4 & 37.7 & 27.6 & 1.9 \\
\hline Willow SRC & Harvested & 99.8 & 39.1 & 14.7 & 13.4 & 4.0 \\
\hline Miscanthus $\times$ giganteus & Rhizome & 31.4 & 28.9 & 33.0 & 10.6 & 5.8 \\
\hline Miscanthus $\times$ giganteus & Stubble & 166.6 & 28.0 & 47.5 & 14.2 & 5.3 \\
\hline Miscanthus $\times$ giganteus & Leaf fall & 60.4 & 35.8 & 37.7 & 6.6 & 11.1 \\
\hline Miscanthus $\times$ giganteus & Harvested & 196.5 & 49.3 & 27.0 & 12.0 & 6.4 \\
\hline Miscanthus sinensis & Rhizome & 33.3 & 28.6 & 25.6 & 9.9 & 5.5 \\
\hline Miscanthus sinensis & Stubble & 78.9 & 32.0 & 43.2 & 11.6 & 6.5 \\
\hline Miscanthus sinensis & Harvested & 134.4 & 46.4 & 32.8 & 8.7 & 9.1 \\
\hline Switchgrass & Harvested & $N A$ & 44.0 & 32.5 & 9.1 & 8.4 \\
\hline Maize variety '34B39' & Stubble + roots & 57.3 & 30.8 & 34.5 & 6.8 & 9.6 \\
\hline Maize variety ' $34 B 39$ ' & Harvested & 43.7 & 24.0 & 27.2 & 3.3 & 15.5 \\
\hline Maize variety Atletico & Stubble + roots & 55.8 & 27.4 & 31.7 & 6.7 & 8.8 \\
\hline Maize variety Atletico & Harvested & 48.1 & 21.0 & 20.7 & 2.5 & 16.7 \\
\hline
\end{tabular}

ADL. All results were expressed on absolute dry matter content taking the residual moisture content into account.

Soil sampling. Two $2 \mathrm{~m} \times 2 \mathrm{~m}$ plots were placed in each subblock according to Fig. S1. In July 2012, from each of these plots, 20 random subsamples $(1 \times 1 \times 5 \mathrm{~cm}$ deep $)$ were collected and pooled to determine soil moisture, soil organic carbon level, soil $\mathrm{pH}, \mathrm{N}$ availability and mineralization, nematode community composition and microbial community composition. Prior to sampling, the litter layer was removed. Prior to analyses, pooled samples were homogenized and sieved using mesh size $2 \mathrm{~mm}$ to remove coarse root material and stones. Soil samples for assessing arthropod numbers were taken from the upper $5 \mathrm{~cm}(10 \times 10 \times 5 \mathrm{~cm}$ deep $)$ from the same plot on the same day. To determine earthworm numbers, soil samples $(30 \times 30 \times 15 \mathrm{~cm}$ deep $)$ were taken only in plots 1,3 , and 5 (Fig. S1). To determine differences in soil aggregation between the different crops, a set of 20 subsamples of $1 \times 1 \times 5 \mathrm{~cm}$ deep was collected from the same plots in August 2013.

Soil abiotics. To determine total soil moisture, a subsample of $25 \pm 2 \mathrm{~g}$ of field soil was air-dried at $70^{\circ} \mathrm{C}$ during $48 \mathrm{~h}$. The TOC concentration in the soil was measured on oven-dried $\left(70^{\circ} \mathrm{C}\right)$ soil samples using dry combustion at $1050^{\circ} \mathrm{C}$ with a Skalar Primacs SLC TOC-analyzer, according to ISO 10694. Total N content was determined by dry combustion (Dumas principle) with a Thermo flash 4000 according to ISO 13878.

Total net $\mathrm{N}$ mineralization was determined using a subsample of $25.0 \pm 0.1 \mathrm{~g}$. This sample was split into two. Half of the sample (12.5 $\mathrm{g} \pm 0.05 \mathrm{~g})$ was used to determine availability of $\mathrm{NO}_{3}-\mathrm{N}$ and $\mathrm{NH}_{4}-\mathrm{N}$, using $\mathrm{KCl}$ extraction. After $25 \mathrm{ml}$ of demi water was added, the sample was incubated on a flatbed shaker $(250 \mathrm{rpm}, 2 \mathrm{~h})$ and $\mathrm{pH}_{\left(\mathrm{H}_{2} \mathrm{O}\right)}$ was determined. Afterwards, $25 \mathrm{ml}$ of $2 \mathrm{M} \mathrm{KCl}$ was added to each sample, and samples were again incubated on a flatbed shaker for $2 \mathrm{~h}$ at $250 \mathrm{rpm}$. Clear $1.5 \mathrm{ml} \mathrm{KCl}$ extractions were obtained by centrifuging at $10285 \mathrm{~g}$, and samples were stored at $-20^{\circ} \mathrm{C}$ for one month, after which availability of $\mathrm{NO}_{3}-\mathrm{N}$ and $\mathrm{NH}_{4}-\mathrm{N}$ was determined using an autoanalyser (SEAL QuAAtro SFA system, Beun- de Ronde B.V. Abcoude, The Netherlands). The other half of the sample was incubated at $20^{\circ} \mathrm{C}$ in the dark for 20 days at constant moisture conditions, after which $\mathrm{NO}_{3}-\mathrm{N}$ and $\mathrm{NH}_{4}-\mathrm{N}$ availability was determined using the same procedure. The difference between the plant available $\mathrm{N}$ in both measurements was taken as the potentially mineralized $\mathrm{NO}_{3}-\mathrm{N}$ and $\mathrm{NH}_{4}-\mathrm{N}$.

Soil aggregates were determined using wet sieving (mesh sizes $2 \mathrm{~mm}, 0.5 \mathrm{~mm}, 0.25 \mathrm{~mm}$ ), using the method of Six et al. (1998). The smallest mesh size $(53 \mu \mathrm{m})$ was discarded because of the high sand content.

Soil biota. Composite samples were homogenized thoroughly, and nematodes were extracted from a $100 \mathrm{~g}$ subsample using an elutriator (Oostenbrink, 1960). Nematodes were identified to family level from a sample of $100 \mathrm{ml}$ of soil. The first 100 individuals of each sample were identified, and the total number of nematodes was determined by counting all nematodes in 1/10 of the sample. Maturity index was calculated following Bongers (1990). Nematode communities were analysed using multivariate statistics (NMDS) in R (Version 3.0.1), based on the number of individuals per nematode family.

Differences in fungal and bacterial biomass, fungal/bacterial ratio, and biomass of arbuscular mycorrhizal fungi (AMF) among soils from the different bioenergy crops were assessed using phospholipid-derived fatty acids (PLFA) and neutral lipid fatty acids (NLFA), respectively, from a subsample of $6 \mathrm{~g}$ of freeze-dried dried soil. The PLFAs i-15:0, a-15:0, 15:0, i-16:0, 17:0, cyclo-17:0, 18:1v7 and cyclo-19:0 were used as bacterial markers and PLFA 18:2v6 was used as an indicator of fungal biomass (Frostegård \& Bååth, 1996). The ratio of fungal to bacteria was used as an indicator of shifts in the relative abundance of these groups (Bardgett et al., 1996). NLFA 18:2 $\omega 6$ was used to determine AMF biomass (Ngosong et al., 2012). Extraction of microarthropods was carried out by transferring soil samples directly to Tullgren extraction funnels with mesh size $1 \mathrm{~mm}$ (Siepel, 1996). 
Individuals were stored in $70 \%$ alcohol and identified to morphospecies. Earthworms were hand sorted in situ and counted.

Plant species cover and richness in the understory of the different plots of maize, Miscanthus, switchgrass, and willow SRC were recorded in August 2013 in each $2 \times 2 \mathrm{~m}$ sampling plot (Fig. S1), using a decimal scale (Londo, 1976). To use vegetation composition as an estimation of the soil fertility, we calculated the average Ellenberg $N$ (Ellenberg et al., 1991) for each of the plant communities (Schaffers \& Sýkora, 2000).

\section{Greenhouse experiment}

From each of the six sub-blocks from Miscanthus $\times$ giganteus, willow SRC, and maize var. Atlantico, five intact soil cores of $22 \mathrm{~cm}$ deep and $12 \mathrm{~cm}$ diameter were taken on 27 September 2012, resulting in a total number of 90 cores. To avoid regrowth of bioenergy crops, all cores were taken at least $15 \mathrm{~cm}$ away from the nearest plant. Coarse litter, mosses, and living plants were removed from the top of these cores. Cores were assigned to five different treatments: (1) a soil pathogen treatment, (2) a leaf pathogen treatment, (3) a nutrient treatment, plus two control treatments: (4) a leaf pathogen control treatment (henceforth LP control and (5) a soil pathogen + nutrient control treatment (henceforth $(\mathrm{S}+\mathrm{N}$ control). The LP control was installed because growing conditions of the leaf pathogen treatment were quite different from the other three treatments. Each treatment included 18 cores: 6 cores from each of the three bioenergy soils.

Two days after transport to the laboratory, nine wheat seeds (Triticum aestivum $\mathrm{cv}$. Carenius) were sown in all soil cores, in a grid with $3 \mathrm{~cm}$ between the seeds, at a depth of approximately $5 \mathrm{~mm}$. Prior to planting, all seeds had been sterilized with $5 \%$ bleach for $3 \mathrm{~min}$ and rinsed off with demineralized water. Seeds that had not emerged after 1 week were sown again. To maintain a constant number of seedlings in all pots, we removed all new seedlings when there were already five per pot. Pots were watered three times per week, with $30 \mathrm{ml}$ per week in the first two weeks and $60 \mathrm{ml}$ per week in the following weeks. Weeds were removed every 7 days.

To test soil suppressiveness against fungal pathogens, we inoculated one treatment with a soil pathogen (Rhizoctonia solani AG13) and one treatment with a leaf fungal pathogen (Mycosphaerella graminicola). In the soil pathogen treatment, $\varnothing$ $3 \mathrm{~mm}$ agar plugs from a 5-day culture of Rhizoctonia solani AG13 were inserted 7 days after the seedling emergence, at $0.5-1 \mathrm{~cm}$ below the base of two average sized seedlings in each pot. In the $\mathrm{S}+\mathrm{N}$ control, sterile agar plugs were inserted below the base of two average sized seedlings.

In the leaf pathogen treatment and the LP control, 6 cores per soil type (18 cores in total) were placed in separate chambers with RH $95-100 \%$, to maintain high humidity and minimize contamination risk to the other treatments. Yeast-like cells of Mycosphaerella graminicola were grown in liquid yeastsucrose medium (YSM: yeast extract $10 \mathrm{~g} \mathrm{l}^{-1}$, sucrose $10 \mathrm{~g} \mathrm{l}^{-1}$ ). The medium was distributed in 250-ml flasks, and a small plug of the isolate of M. graminicola IPO 323 was transferred into the liquid medium. The inoculated liquid medium was cultured on a flatbed shaker at $150 \mathrm{rpm}$ and $18^{\circ} \mathrm{C}$, for 8 days when spore concentration typically is around $10^{7}-10^{8}$. Each pot in the leaf pathogen treatment received $2 \mathrm{ml}$ of inoculum, which was dispersed using a hand-held sprayer, on the same day that all pots were placed in the high-humidity chamber. LP controls were sprayed with a similar amount of demineralized water.

To detect the carry-over effect of this leaf pathogen on plant quality, we used a leaf herbivore, three (flightless) adults, and seven juvenile aphids of the Graminae-specific aphid Rhopalosiphum padi were introduced on all pots in the leaf pathogen treatment and the LP control. Aphids could disperse freely between pots within each treatment as leaves of the plants were touching each other. Two days after introduction of aphids, adult and juvenile aphid abundance was determined by recollecting aphids from all pots.

The nutrient treatment was installed to examine for the effect of nutrients on wheat growth. In this treatment, 10 grams of dried cow manure (mineral $\mathrm{N}=2.9 \%, \mathrm{P}_{2} \mathrm{O}_{5}=3.2 \%$, $\mathrm{K}_{2} \mathrm{O}=3.7 \%$ on $\mathrm{DM}$ ) was mixed through the first centimetre of soil prior to sowing.

Plants from all treatments were harvested 49 days after sowing. Aboveground biomass was estimated for each individual plant, both fresh and dry, while dry belowground biomass was determined only for the whole pot.

\section{Data handling and statistics}

To test for differences among effects of bioenergy crops on soil parameters, we used a nested ANOVA design, because subplots were not independent within block, 'Crop species' and 'block' were used as fixed factors, and 'sub-block' was nested in 'block'. This was carried out for the field results, as well as for the greenhouse study. Interaction effects between crop and block were not included in the final model as they were not significant. Differences among crop-specific effects on $\mathrm{C}$ and $\mathrm{N}$ fluxes and earthworm abundances were tested using a oneway ANOVA as only one of the sub-blocks in each of the blocks was sampled. Prior to each analysis, a Kolmogorov-Smirnov test was carried out to check for a normal distribution of the response variable. Residuals were also checked on normality, and data were checked on homogeneity of variances. To meet assumptions on normality, data of species abundance of microarthropods and earthworms were log-transformed prior to analysis. C-P values for nematode communities in the different treatments were compared using a paired $t$-test. Post hoc Tukey's tests were carried out to check for differences between treatments. All statistics were carried out using Statistica 11.0, and graphs were made using SigmaPlot 12.5. A Bray-Curtis dissimilarity metric was used to determine distances between the sampling points, for which we used metaMDS function in the $\mathrm{R}$ vegan package (Anonymous, 2011; Oksanen et al., 2011).

\section{Results}

Crop yields, biochemical composition and effects of bioenergy crops on $\mathrm{C}$ and $\mathrm{N}$ fluxes

From 2009 to 2013, average crop yield was highest for Miscanthus $\times$ giganteus $(21.8 \pm$ SD $4.9 \mathrm{t}$ dry matter 
$\left.\mathrm{ha}^{-1} \mathrm{yr}^{-1}\right)$ and willow SRC (18.5 \pm SD $3.8 \mathrm{t}$ dry matter $\mathrm{ha}^{-1} \mathrm{yr}^{-1}$, Fig. 1). Maize var. Atletico $(17.1 \pm$ SD $2.2 \mathrm{t}$ dry matter $\mathrm{ha}^{-1} \mathrm{yr}^{-1}$ ) and maize var. '34B39' (16.1 \pm SD $1.1 \mathrm{t}$ dry matter $\mathrm{ha}^{-1} \mathrm{yr}^{-1}$ ) had intermediate yields (Fig. 1), whereas switchgrass (11.3 \pm SD $3.1 \mathrm{t}$ dry matter $\mathrm{ha}^{-1} \mathrm{yr}^{-1}$ ) and Miscanthus sinensis (9.6 \pm SD $5.8 \mathrm{t}$ dry matter $\mathrm{ha}^{-1} \mathrm{yr}^{-1}$ ) had the lowest yield (Fig. 1). These differences between crops are also illustrated in $\mathrm{C}$ biomass removed as harvested crop (Table 1). Because switchgrass and $M$. sinensis biomass was even lower than for maize, results presented here on $\mathrm{C}$ and $\mathrm{N}$ cycling largely focus on maize, Miscanthus $\times$ giganteus and willow SRC. Harvested biomass was the largest compartment of carbon for each of the three crops (Table 1).

Among bioenergy crops, clear differences were detected in $\mathrm{C}$ and $\mathrm{N}$ stocks (Table 1). Belowground $\mathrm{C}$ stocks (roots+stubble) were four times higher for willow than for Miscanthus $\times$ giganteus (Tukey: $P<0.001$ ), whereas $C$ input (fluxes) through leaf fall was comparable between these species (Tukey: $\mathrm{P}=\mathrm{NS}$ ). Leaf fall for willow was highest in the third year of the cycle. In autumn 2013, the first year of the next cycle, leaf fall was only $1100 \mathrm{~kg} \mathrm{C} \mathrm{ha}^{-1}$, whereas the same amount of leaf fall for Miscanthus was recorded as in the previous growing season, that is $2338 \mathrm{~kg} \mathrm{C} \mathrm{ha}^{-1}$. The yearly $\mathrm{N}$ flux from soil to the crop was highest for both maize varieties (appr. $160 \mathrm{~kg} \mathrm{~N} \mathrm{ha}^{-1}$ ), intermediate for willow SRC and lowest for Miscanthus $\times$ giganteus (appr. $95 \mathrm{~kg}$ $\mathrm{N} \mathrm{ha}{ }^{-1}$ ). $\mathrm{N}$ return to the soil was strongly different between crops. For both maize varieties, only $15 \%$ of $\mathrm{N}$ in crop returned as stubble and root biomass, while at least $30 \%$ of the $\mathrm{N}$ in the total aboveground biomass was recycled through leaf fall for willow SRC and both Miscanthus species (Table 1). Besides differences in C and $\mathrm{N}$ fluxes, we also observed differences in biochemical composition and $\mathrm{HC} / \mathrm{L}$ ratio of the plant parts (Table 2). A comparison among the three most productive bioenergy crops (willow SRC, maize var. Atletico, Miscanthus $\times$ giganteus) shows clear differences in lignin content in leaf litter $\left(\mathrm{F}_{(2,6)} 303.1, P<0.001\right)$. A post hoc Tukey's test shows $4 \mathrm{x}$ higher lignin content in willow SRC than in maize $(P<0.001)$ and twice as high as to Miscanthus $(P<0.01)$.

\section{Effects of bioenergy crops on soil parameters}

Total organic carbon (TOC) concentration in the upper $(0-5 \mathrm{~cm})$ soil layer was different among bioenergy crops $\left(F_{(3,13)} 8.7 ; P<0.005\right)$. TOC was higher in willow SRC than in Miscanthus, switchgrass, or maize (Fig. 2). No significant differences in TOC were found between maize, Miscanthus and switchgrass (Fig. 2). Potential N mineralization was different among bioenergy crops
$\left(F_{(3,13)} 11.3 ; P<0.001\right.$, Fig. 2$)$ and was higher in willow SRC than in maize soil (Tukey's test: $P<0.001$ ). There was a correlation between TOC and potential $\mathrm{N}$ mineralization, indicating that soil fertility increased with organic carbon content $\left(R^{2} 0.25, P=0.02\right)$.

A comparison between four bioenergy crop species showed significant differences in total soil aggregation among soils $\left(F_{(3,13)} 37.9 ; P<0.001\right)$, indicating differences in biological activity. Of the different fractions, only the microaggregate fraction was significantly different among bioenergy crops (Fig. 3). Soil $\mathrm{pH}_{\mathrm{H}_{2} \mathrm{O}}$ was

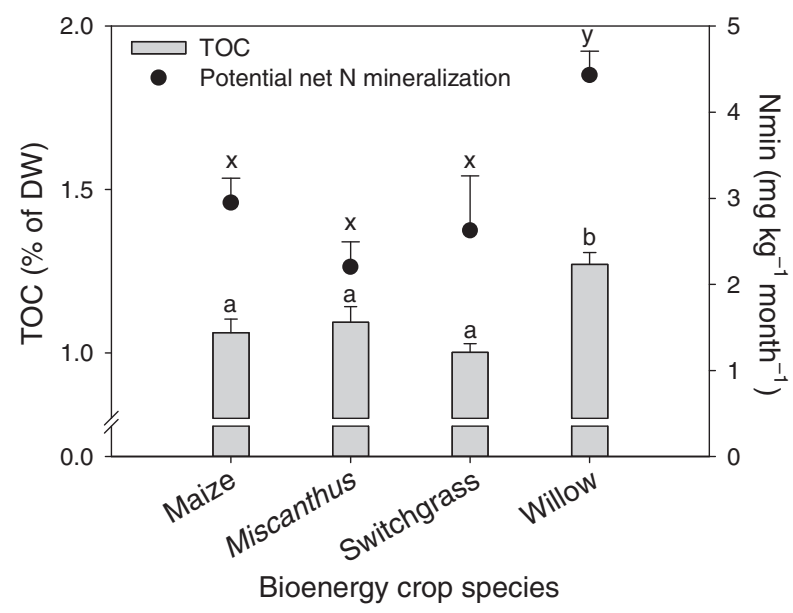

Fig. $2 \mathrm{~N}$ mineralization (black circles) and differences in total organic carbon (TOC) (grey bars) in top $5 \mathrm{~cm}$ between the different crops. Different letters indicate significant differences at $\alpha<0.05$; error bars represent SEM. DW: soil dry weight.

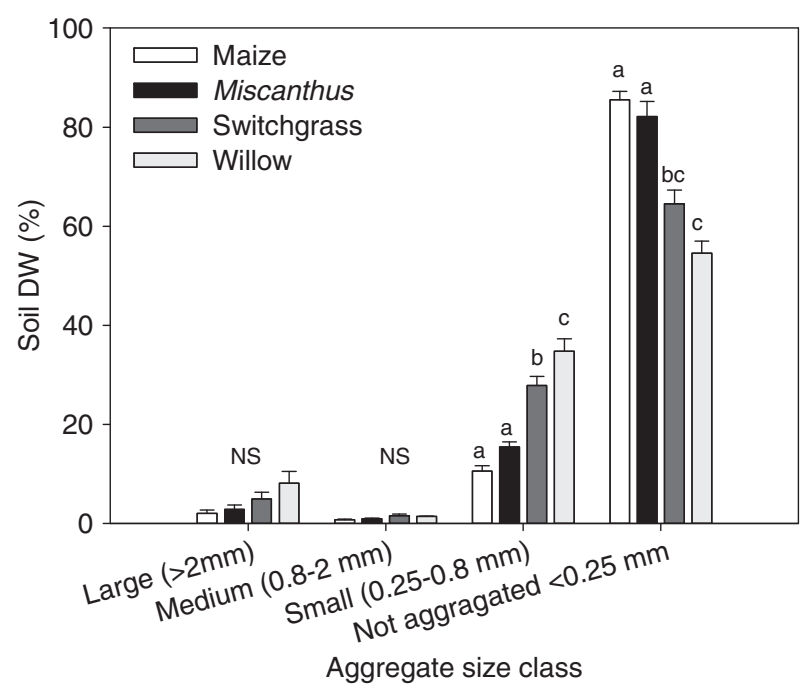

Fig. 3 Soil aggregate size classes in the different bioenergy crop species (for each crop: $\mathrm{N}=6$ ). Different letters indicate statistical differences at $\alpha<0.05$; error bars represent SEM. DW, soil dry weight. 
also different among crops $\left(F_{(3.13)} 15.1, P<0.001\right)$, with the highest mean value in willow SRC and the lowest value in maize (6.62 vs. 6.09 , Tukey's test: $P<0.001$; Fig. S2A).

Earthworm abundances were not different among willow SRC, Miscanthus and switchgrass. However, in all these crops abundances were ten-fold higher than in maize $\left(F_{(3,5)} 54.4 ; P<0.001\right.$; Fig. S2B). Soil arthropod abundance and diversity were higher in willow SRC than in maize soil (Fig. 4). There was no difference in the number of nematode families or nematode abundances among the different soils. However, the $\mathrm{CP}$ value (maturity index) for willow SRC (2.8) was higher than for maize $(2.3),\left(t_{(5)} 3.1, P=0.02\right)$, indicating a more

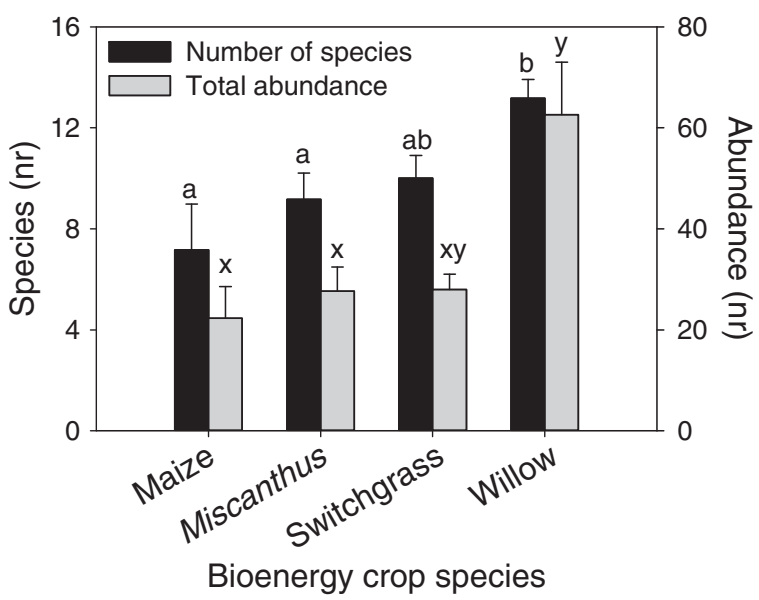

Fig. 4 Total number of species of mites and springtails (black bars) and total abundance of mites and springtails (grey bars) in each of the different soils. Statistics were performed on log-transformed data. Different letters indicate statistical differences at $\alpha<0.05$; error bars represent SEM. 'Miscanthus' represents Miscanthus $\times$ giganteus. 'mature' nematode community with higher numbers of predators and omnivores in the willow SRC plots. No significant differences were found for CP values between maize and Miscanthus. The multivariate analysis, which was based on the number of individuals in each nematode family, also shows divergence between nematode communities in the different soils (Fig. S3).

Results from the PLFA analyses indicated differences in fungal and bacterial biomass among bioenergy crops (fungi: $F_{(3,12)} 10.2, \quad P=0.001 ; \quad$ bacteria: $F_{(3,12)} \quad 4.5$, $P=0.02$; Fig. 5a). Fungal/bacterial (F/B) ratio was higher in willow SRC than in maize (Tukey: $P=0.001$ ) and Miscanthus (Tukey: $P=0.004$; Fig. 5b). AMF biomass (NLFA 16:1 $\omega 5)$ was higher in switchgrass than in the other crops $\left(F_{(3,12)} 9.5 ; P=0.002\right)$; no significant differences were found in AMF biomass between the other crops (Fig. S4).

Cover of understory vegetation was different between crops $\left(F_{(3,13)} 20.0, P<0.001\right)$, with the highest cover in willow SRC $(29.1 \%)$ and the lowest in maize $(0.2 \%)$. Vegetation Ellenberg $\mathrm{N}$ values were not different among willow SRC (6.3), Miscanthus (6.2), and maize (6.0), but were lower for switchgrass $(4.9)\left(F_{(3,9)} 5.2, P=0.02\right.$; Fig. $\mathrm{S} 5)$, indicating lowest fertility in switchgrass plots.

\section{Legacy effects of bioenergy crops on wheat growth}

Wheat biomass in the greenhouse bioassay was highest on willow SRC soil cores, over all treatments, both aboveground ( $F \quad(2,44) 23.4 ; \quad P<0.001 ;$ Fig. 6) and belowground $\left(F_{(2,44)} 6.8 ; P=0.003\right.$; data not shown). In the $\mathrm{S}+\mathrm{N}$ control, wheat biomass on willow SRC soil was almost twice as high as on Miscanthus and maize soil $\left(F_{(2,9)} 11.8 ; P=0.004\right)$. In the nutrient treatment, biomass of wheat was on average 150-200\% higher than in the $\mathrm{S}+\mathrm{N}$ control $\left(F_{(1,27)} 131.1 ; P<0.001 ;\right.$ Fig. 6). With
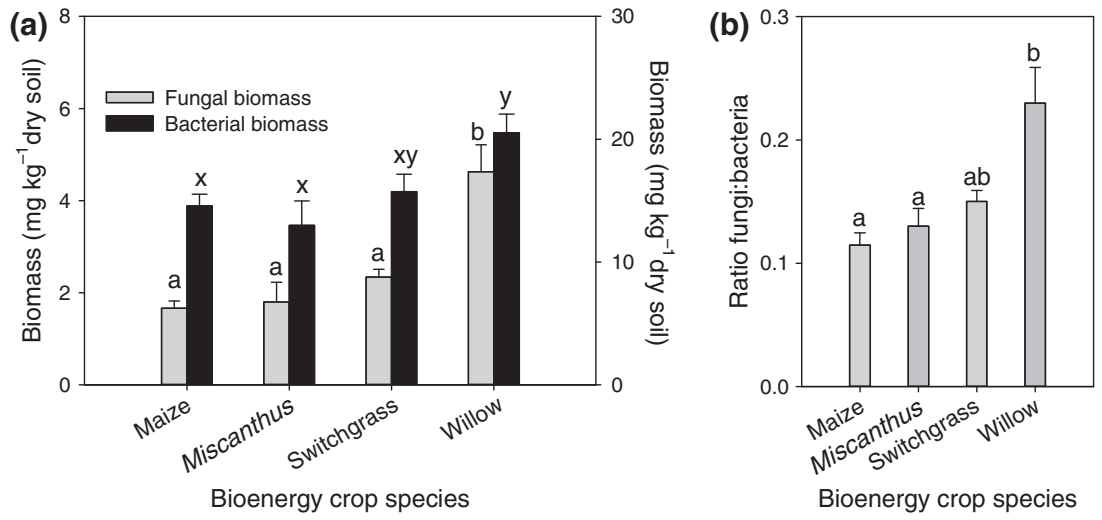

Fig. 5 Fungal (grey bars) and bacterial biomass estimates (black bars) (a) and fungal/bacterial ratio (b) in the different bioenergy crop species. Note that in (a), left $y$-axis denotes fungal biomass (grey bars) and right $y$-axis has bacterial biomass (black bars). Different letters indicate significant differences at $\alpha<0.05$; error bars represent SEM. Miscanthus represents Miscanthus $\times$ giganteus. 


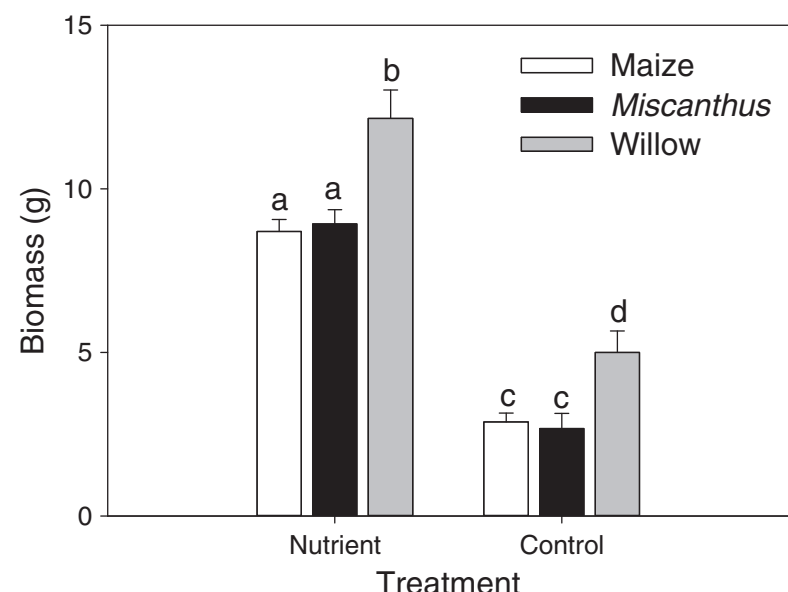

Fig. 6 Aboveground dry matter biomass of wheat plants (in grams) in the nutrient treatment (left) and control treatment (right). White bars: maize soil, black bars: Miscanthus $\times$ giganteus soil, grey bars: willow SRC soil. Different letters indicate statistical differences at $\alpha<0.05$; error bars represent SEM.

the exception of the nutrient treatment, no differences were found among the treatments on willow SRC soil. Total wheat biomass in the soil pathogen treatment was not different from the $\mathrm{S}+\mathrm{N}$ control (interaction soil type $\times$ treatment: $\left.F_{(2,28)} 0 ; P=\mathrm{NS}\right)$. However, when focusing only on the plants that were directly infected with $R$. solani, we found a reduction in wheat biomass in plants that were infected with $R$. solani, compared with plants in the $\mathrm{S}+\mathrm{N}$ control $\left(F_{(2,28)} 4.90 ; P=0.01\right.$; Fig. 7a). This difference was significant for Miscanthus soil (Tukey, $P=0.03$; Fig. 7a), while the difference on maize soil was marginally nonsignificant (Tukey, $P=0.09$; Fig. $7 \mathrm{~b}$ ). Also, wheat biomass on Miscanthus soil was significantly lower in the presence of soil pathogens than in the control treatment $\left(F_{(2,28)} 4,13\right.$; $P=0.03$, Fig. $7 \mathrm{~b})$.

Our results show a pronounced effect of previous crop and pathogen infection on aphid abundance. After $48 \mathrm{~h}$, wheat plants on willow SRC soil had 1.5 times more adult aphids and two times more juvenile aphids than plants on maize or Miscanthus soil, but no difference was recorded between the number of aphids on wheat on Miscanthus soil or maize soil (Figs 8a,b). Juvenile aphid numbers were lower on wheat growing on maize and Miscanthus soils when plants were infected with M. graminicola, whereas on willow SRC soil aphid numbers were not statistically different between pathogen-infected and noninfected plants.

\section{Discussion}

Growth of bioenergy crops should not go at the expense of the provisioning of soil ecosystem services (Lal,
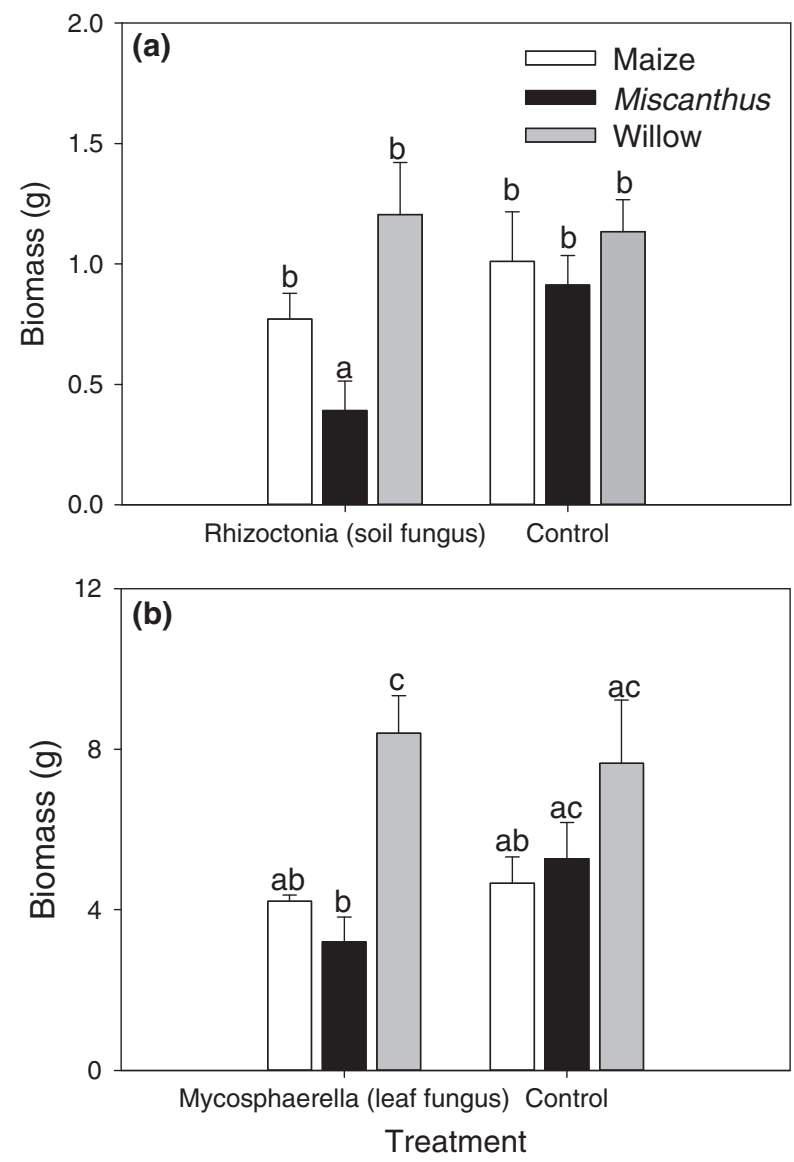

Fig. 7 Aboveground dry matter biomass of wheat plants (in grams) in (a) belowground fungal pathogen treatment (Rhizoctonia solani) and (b) aboveground fungal pathogen treatment (Mycosphaerella graminicola). Biomass in (a) shows the average biomass for the directly infected plant and an average control plant, while in (b) biomass denotes the total biomass for all plants in one pot. White bars: maize soil, black bars: Miscanthus $\times$ giganteus soil, grey bars: willow SRC soil. Similar letters indicate no statistical differences $(\alpha<0.05)$; error bars represent SEM.

2005). To produce yields in a sustainable way, crops need to improve or maintain soil functioning rather than decrease it (sensu Foley et al., 2005). Our results show pronounced differences among bioenergy crops and their effects on the provisioning of soil ecosystem services including water retention, soil fertility, and pathogen suppression. Three of the four studied crops sustained high yields during a period of 6 years. Yields of maize could only be sustained by substantial fertilizer application. The fourth crop, switchgrass had almost 50\% lower yield than the highest yielding crop, Miscanthus, which is in line with other recent estimates (Arundale et al., 2014). Therefore, we excluded switchgrass from further discussion. In the present trial, 

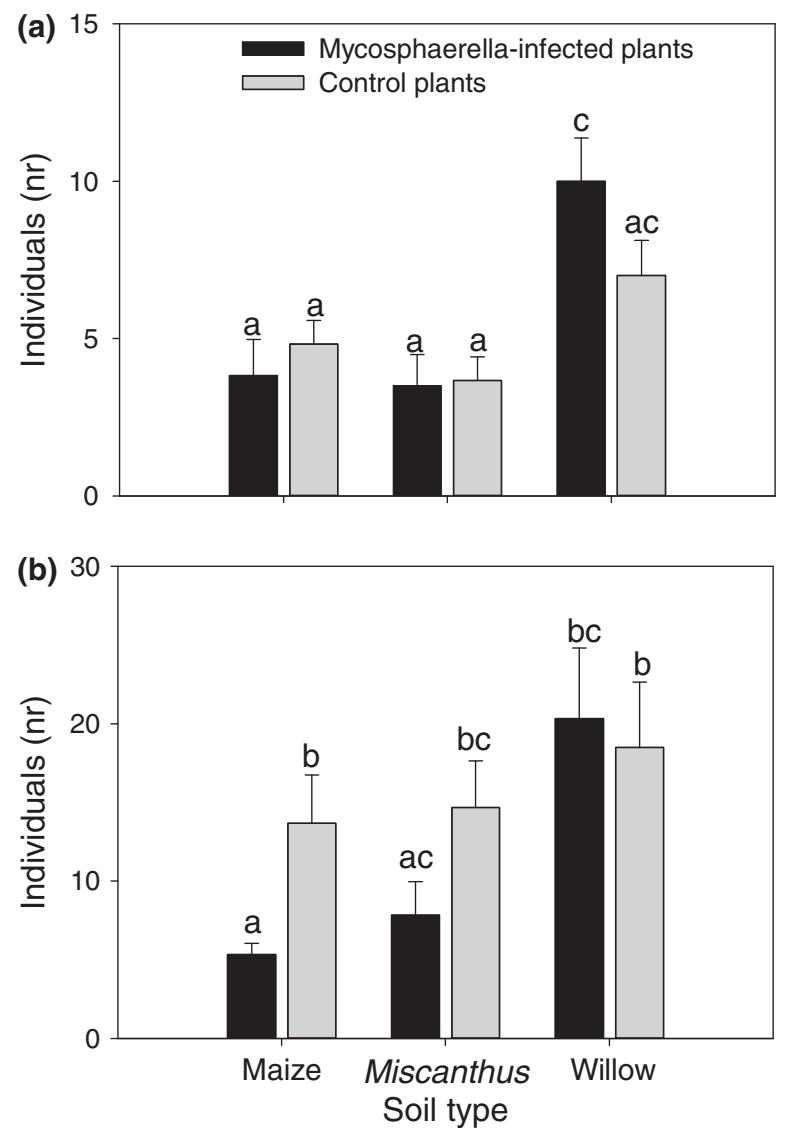

Fig. 8 Adult aphid numbers (a) and juvenile aphid numbers (b) on wheat plants growing in the different soil types. Mycosphaerella-infected pots are indicated with black bars; control treatments are indicated with grey bars. Similar letters indicate no statistical differences $(\alpha<0.05)$; error bars represent SEM. 'Miscanthus' represents Miscanthus $\times$ giganteus.

willow SRC had the most positive effect on provisioning soil ecosystem services, when compared to maize, and had positive effects on the follow-up crop, wheat. Miscanthus and switchgrass, on the other hand, did not provide a soil legacy that was substantially different from maize.

Compared with maize, willow SRC had an overall positive effect on soil abiotic and biotic properties and subsequent wheat crop growth. In contrast, the other second-generation bioenergy crop, Miscanthus had a negative effect on wheat production when compared to maize. As soil $\mathrm{pH}$ was well into the range for optimal wheat growth (Islam et al., 1980), it appears unlikely that crop-specific effects on $\mathrm{pH}$ have been driving the observed effects on wheat growth. Differences of harvesting regimes could potentially explain some of the observed differences among crops. Management regimes that lead to lower soil disruption may result in enhanced build-up of TOC and biodiversity (Six et al.,
2000). However, even though a no-tillage regime was practised in both Miscanthus and switchgrass stands, TOC values were comparable to those of maize, which required annual soil tillage. Therefore, we conclude that it is unlikely that soil management alone can explain the observed differences in soil legacy between the bioenergy crops in this trial. It seems more likely that the legacy effects are crop species specific.

\section{Effect of bioenergy crops on $C$ and $N$ fluxes}

Our results show that soil under willow SRC has a higher soil fertility and soil carbon than any of the other bioenergy crops. Key to understanding the effects of the different crops on soil ecosystem functioning is the crop-specific impact on $\mathrm{C}$ and $\mathrm{N}$ fluxes to the soil in the form of crop residues. Miscanthus is known to translocate the majority of $\mathrm{N}$ to belowground organs in autumn (83\% according to Long et al., 2001). Our results show that maize returns only $15 \%$ of $\mathrm{N}$ to the soil via roots and stubbles. Willow, on the other hand, translocates only $40-50 \%$ of $\mathrm{N}$ to its roots in autumn (Von Fircks et al., 2001). This results in substantial differences in the amount of $\mathrm{N}$ that is returned to the soil. For willow $\mathrm{SRC}$, most of the $\mathrm{N}$ returns to the soil via leaf fall, whereas $\mathrm{N}$ content in leaf fall is negligible for Miscanthus. As a result willow enhances fertility in the upper soil layer, whereas maize and Miscanthus have far lower soil fertility. Likewise, differences in TOC can be ascribed to crop-specific differences in carbon return to the soil surface. Several studies have reported a positive effect of woody crops on TOC, often with the strongest increase in the top layer (Grogan \& Matthews, 2002; Liberloo et al., 2009; Blanco-Canqui, 2010; Hellebrand et al., 2010; Lasch et al., 2010), thus supporting our results. Another study that compared different bioenergy crops also found more positive effects of willow SRC on TOC than switchgrass, Miscanthus or maize (Zan et al., 2001). Some studies have reported or modelled an increase in SOM levels after planting switchgrass and Miscanthus (Beuch et al., 2000; Kahle et al., 2001; Qin et al., 2012), but others found no effect, or effects that were strongly dependent on soil type and initial organic matter percentage (Bainard et al., 2013). This result may seem counterintuitive, given that the total biomass production in Miscanthus was higher than in willow SRC. Besides, willow litter had the lowest C:N ratio. An explanation could be that, besides a lower C:N ratio, willow leaf litter also had a higher recalcitrant fraction (lignin) (Table 2). Previous studies on organic matter formation have shown that lignin forms an important contribution to the organic matter pool (Berg, 2000; Liberloo et al., 2009). Moreover, high N availability, as found for willow leaf fall, may strongly retard degradation of 
lignin (Berg, 2000). Our results therefore suggest that the high lignin input of willow leaves plays a key role in increasing the TOC levels in willow SRC top soil.

Arbuscular and ectomycorrhizal fungi (AMF and EEM) play a major role in soil carbon sequestration (De Deyn et al., 2008; Rooney et al., 2009), but in general, EEM fungi have been found to be more important for carbon sequestration than AMF (Averill et al., 2014). Indeed, results from our PLFA/NLFA analysis show that switchgrass soil had the highest AMF biomass, but the lowest TOC levels, suggesting that AMF do not play a major role in sequestering soil carbon in our experiment. Cropping willow SRC, on the other hand, resulted in a stronger increase in TOC than any of the other crops, suggesting that EEM fungi under willow could play an important role in soil carbon sequestration. Willow SRC soils also had a more aggregated soil and a greater soil biodiversity. This result is largely in line with those from agroforestry experiments (Barrios et al., 2012), suggesting that growing woody plants, together, or in rotation with herbaceous crop species might enhance both soil properties and crop performance.

Our results show positive legacy effects of willow SRC on a subsequent crop. Wheat biomass on willow SRC soil was higher than on maize or Miscanthus soil. Again, this opposes our hypothesis because we expected similarly positive effects for all second-generation bioenergy crops. These results likely reflect the crop-specific changes in soil physical parameters. Cropspecific changes in TOC levels could explain the legacy effect on a subsequent crop in different ways. Higher TOC levels under willow SRC may lead to higher soil fertility (Janzen, 2006), which could enhance biomass production of a subsequent crop. Indeed, we found higher potential $\mathrm{N}$ mineralization in soil from willow SRC than from all other crops. However, nutrient additions in the greenhouse did not completely remove the differences in wheat growth among soils, suggesting that changes in soil fertility alone cannot explain the positive effects of willow SRC on wheat growth.

Higher TOC levels may contribute to greater pathogen suppression through a higher overall soil activity and increased fungal/bacterial ratio (Hoitink \& Boehm, 1999; Van Bruggen \& Semenov, 2000; Garbeva et al., 2006). Our results showed that willow SRC soils had higher organic $\mathrm{C}$ levels and fungal and bacterial biomass, which may explain stronger disease suppression (Hoitink \& Boehm, 1999; Raaijmakers et al., 2009). Alternatively, salicylic acid can be excreted by willows in substantial quantities (Schmidt et al., 2000), which could have triggered the salicylic acid pathway in plants (Jayaraj et al., 2004), thus resulting in disease suppression. However, a previous study on willow suggests that sali- cylic acid under willow is short-lived as it is quickly metabolized by salicylic acid degrading micro-organisms (Schmidt et al., 2000). This would suggest that the time between taking soil cores from the field and growth of the young wheat seedlings (five days) may have been too long for the salicylic acid to remain intact in the soil matrix.

The question remains whether the positive effects of willow SRC as a second-generation biomass crop on soil ecosystem properties is unique to willow species or represent a more general phenomenon. Recent results from long-term poplar plantations seem to point at a similar conclusion (Sierra et al., 2013), suggesting that a wider range of tree species may have similar positive effect on soil legacy. Another important question is how long positive legacy effects can remain. If operating via an increase in TOC, insight is needed into longterm TOC dynamics in agricultural soil. Especially if TOC becomes stabilized in soil aggregates, as suggested by our results, these effects may be long lasting (Six et al., 2000). However, tillage is known to disrupt aggregates and decrease TOC (Six et al., 1999), so that the length of the legacy effect may depend on till vs. no till management.

Ultimately, the magnitude and longevity of the positive legacy effects will be critical determinants for farmers' decisions on which bioenergy crop to grow. Particularly in soils with higher TOC concentrations effects of bioenergy crops on TOC concentration may be small (Blanco-Canqui, 2010). Therefore, including willow SRC plantations in crop rotation could be particularly beneficial on soils with low OM levels. Recent reports on reductions in soil organic matter levels (Bellamy et al., 2005; Taghizadeh-Toosi, 2014) illustrate that inclusion of ecosystem function promoting bioenergy crops in the rotation deserves serious attention.

\section{Conclusions and perspectives}

Our results show that of three second-generation crops tested willow SRC had the most positive effects on soil structure, soil fertility, soil biodiversity, and pathogen suppression in a follow-up crop. For the selected energy crops in the field trial, we found substantial differences in $\mathrm{N}$ and $\mathrm{C}$ cycling, probably as a result of crop-specific biochemical characteristics of the produced organic matter. These differences resulted in greater soil fertility and TOC levels in soil under willow SRC than in soil from each of the other second-generation bioenergy crops.

Our results also suggest that the use of bioenergy crops to augment soil ecosystems services requires careful implementation because not all crops influence soil ecosystem services equally well (Brussaard et al., 2004; 
Foley et al., 2005; Hedlund \& Harris, 2012). Future research should focus on the question whether (1) this effect occurs in the whole spectrum of soil textures and (2) willow species all have similar effects and if they are unique in this respect. Beneficial soil legacy effects (and the lack thereof) should be taken into account in future life cycle assessments of bio-based cropping systems. In addition, crops with positive legacy effects should be considered in future crop rotations or on soils with low TOC levels.

\section{Acknowledgements}

We are greatly indebted to many members of the ILVO and NIOO teams who helped with sampling and measurements. Special thanks go to Pieter Cremelie for the extraction of the PLFA/NLFAs. We are grateful to Puck Oomen and Rosa Keijzer for their help with setting up the laboratory experiment, and to Maarten De Bie for performing the willow root sampling. We want to thank Jos Raaijmakers and Emilie Chapelle for kindly providing Rhizoctonia solani AG13 and Gert Kema and Lamia Aouinni for providing Mycosphaeralla graminicola. We also thank Jeroen van Schaik for providing Rhopalosiphum padi. We thank Wim Dimmers for assistance on arthropod extractions and identification. This research was supported by BE-Basic Grant 8.002.04 to WHvdP and partly financed by project BOD/STUD/2011/02 (Flemish Government).

\section{References}

Anonymous (2011) R: A Language and Environment for Statistical Computing. R Development Core Team, R Foundation for Statistical Computing, Vienna, Austria.

Arundale RA, Dohleman FG, Heaton EA, Mcgrath JM, Voigt TB, Long SP (2014) Yields of Miscanthus $\times$ giganteus and Panicum virgatum decline with stand age in the Midwestern USA. GCB Bioenergy, 6, 1-13.

Averill C, Turner BL, Finzi AC (2014) Mycorrhiza-mediated competition between plants and decomposers drives soil carbon storage. Nature, 505, 543-545.

Bainard L, Koch A, Gordon A, Klironomos J (2013) Growth response of crops to soil microbial communities from conventional monocropping and tree-based intercropping systems. Plant and Soil, 363, 345-356.

Bardgett RD, Hobbs PJ, Frostegård A (1996) Changes in soil fungal: bacterial biomass ratios following reductions in the intensity of management of an upland grassland. Biology and Fertility of Soils, 22, 261-264

Barrios E, Sileshi G, Shepherd KD, Sinclair F (2012) Agroforestry and soil health: Linking trees, soil biota and ecosystem services. In: Soil Ecology and Ecosystem Services (eds Wall D, Bardgett R, Behan-Pelletier V, Herrick J, Jones H, Ritz K, Six J, Strong D, Van Der Putten W), pp. 315-330. Oxford University Press, Oxford.

Bellamy PH, Loveland PJ, Bradley RI, Lark RM, Kirk GJD (2005) Carbon losses from all soils across England and Wales 1978-2003. Nature, 437, 245-248.

Berg B (2000) Litter decomposition and organic matter turnover in northern forest soils. Forest Ecology and Management, 133, 13-22.

Beuch S, Boelcke B, Belau L (2000) Effect of the organic residues of Miscanthus $\times$ giganteus on the soil organic matter level of arable soils. Journal of Agronomy and Crop Science, 184, 111-120.

Blanco-Canqui H (2010) Energy crops and their implications on soil and environment. Agronomy Journal, 102, 403-419.

Bongers T (1990) The maturity index: an ecological measure of environmental disturbance based on nematode species composition. Oecologia, 83, 14-19.

Bourke D, Stanley D, O'Rourke E et al. (2014) Response of farmland biodiversity to the introduction of bioenergy crops: effects of local factors and surrounding landscape context. GCB Bioenergy, 6, 275-289.

Brussaard L, Kuyper T, Didden W, Goede RD, Bloem J (2004) Biological soil quality from biomass to biodiversity-importance and resilience to management stress and disturbance. In: Managing Soil Quality: Challenges in Modern Agriculture (eds Schjønning P, Elmholt S, Christensen BT). CABI, Cambridge.
De Deyn GB, Cornelissen JH, Bardgett RD (2008) Plant functional traits and soil carbon sequestration in contrasting biomes. Ecology letters, 11, 516-531.

De Vries FT, Bloem J, Quirk H, Stevens CJ, Bol R, Bardgett RD (2012a) Extensive management promotes plant and microbial nitrogen retention in Temperate Grassland. PLoS One, doi: 10.1371/journal.pone.0051201.

De Vries FT, Liiri ME, Bjørnlund L, Bowker MA, Christensen S, Setälä HM, Bardgett RD (2012b) Land use alters the resistance and resilience of soil food webs to drought. Nature Climate Change, 2, 276-280.

Djomo SN, Kasmioui OE, Ceulemans R (2011) Energy and greenhouse gas balance of bioenergy production from poplar and willow: a review. GCB Bioenergy, 3, 181-197.

Ellenberg H, Weber HE, Düll R, Wirth V, Werner W, Paulissen D (1991) Zeigerwerte von Pflanzen in Mitteleuropa. Scripta Geobotanica, 18, 1-248.

European Commission (2005) Biomass Action Plan. European Commission, Brussels.

Foley JA, Defries R, Asner GP et al. (2005) Global consequences of land use. Science, 309, 570-574

Frank A, Berdahl J, Hanson J, Liebig M, Johnson H (2004) Biomass and carbon partitioning in switchgrass. Crop Science, 44, 1391-1396.

Frostegård Å, Bååth E (1996) The use of phospholipid fatty acid analysis to estimate bacterial and fungal biomass in soil. Biology and Fertility of Soils, 22, 59-65.

Garbeva P, Postma J, Van Veen J, Van Elsas J (2006) Effect of above-ground plant species on soil microbial community structure and its impact on suppression of Rhizoctonia solani AG3. Environmental Microbiology, 8, 233-246.

Georgescu M, Lobell DB, Field CB (2011) Direct climate effects of perennial bioenergy crops in the United States. Proceedings of the National Academy of Sciences of the United States of America, 108, 4307-4312.

Grogan P, Matthews R (2002) A modelling analysis of the potential for soil carbon sequestration under short rotation coppice willow bioenergy plantations. Soil Use and Management, 18, 175-183.

Hedlund K, Harris J (2012) Delivery of Soil Ecosystem Services: From Gaia to Genes. In: Soil Ecology and Ecosystem Services (eds Wall D, Bardgett R, Behan-Pelletier V, Herrick J, Jones H, Ritz K, Six J, Strong D, Van Der Putten W), pp. 98-109. Oxford University Press, Oxford.

Hellebrand H, Strähle M, Scholz V, Kern J (2010) Soil carbon, soil nitrate, and soil emissions of nitrous oxide during cultivation of energy crops. Nutrient Cycling in Agroecosystems, 87, 175-186.

Hoitink H, Boehm M (1999) Biocontrol within the context of soil microbial communities: a substrate-dependent phenomenon. Annual Review of Phytopathology, 37 427-446.

Islam AKMS, Edwards DG, Asher CJ (1980) $\mathrm{pH}$ optima for crop growth. Plant and Soil, 54, 339-357.

Jandl G, Baum C, Blumschein A, Leinweber P (2012) The impact of short rotation coppice on the concentrations of aliphatic soil lipids. Plant and Soil, 350, 163-177.

Janzen H (2006) The soil carbon dilemma: shall we hoard it or use it? Soil Biology and Biochemistry, 38, 419-424.

Jayaraj J, Muthukrishnan S, Liang G, Velazhahan R (2004) Jasmonic acid and salicylic acid induce accumulation of $\beta$-1, 3-glucanase and thaumatin-like proteins in wheat and enhance resistance against Stagonospora nodorum. Biologia Plantarum, 48, 425-430.

Kahle P, Beuch S, Boelcke B, Leinweber P, Schulten H-R (2001) Cropping of Miscanthus in Central Europe: biomass production and influence on nutrients and soi organic matter. European Journal of Agronomy, 15, 171-184.

Lal R (2005) World crop residues production and implications of its use as a biofuel Environment International, 31, 575-584.

Lasch P, Kollas C, Rock J, Suckow F (2010) Potentials and impacts of short-rotation coppice plantation with aspen in Eastern Germany under conditions of climate change. Regional Environmental Change, 10, 83-94.

Lemus R, Lal R (2005) Bioenergy crops and carbon sequestration. Critical Reviews in Plant Sciences, 24, 1-21.

Liberloo M, Lukac M, Calfapietra C et al. (2009) Coppicing shifts CO2 stimulation of poplar productivity to above-ground pools: a synthesis of leaf to stand level results from the POP/EUROFACE experiment. New Phytologist, 182, 331-346.

Liebig MA, Schmer MR, Vogel KP, Mitchell RB (2008) Soil carbon storage by switchgrass grown for bioenergy. BioEnergy Research, 1, 215-222.

Londo G (1976) The decimal scale for relevés of permanent quadrats. Vegetatio, 33, $61-64$.

Long S, Beale C, Farage P (2001) Resource capture by Miscanthus. In: Miscanthus for Energy and Fibre (eds Jones M, Walsh M), pp. 10-20. James \& James Ltd., London.

Maskina M, Power JF, Doran JW, Wilhelm W (1993) Residual effects of no-till crop residues on corn yield and nitrogen uptake. Soil Science Society of America Journal, $57,1555-1560$. 
Millenium Ecosystem Assessment (2005) Ecosystems and Human Well-Being. Millenium Ecosystem Assessment, Washington.

Muylle H, Van Hulle S, De Vliegher A, Baert J, Van Bockstaele E, Roldán-Ruiz I (2014) Yield and energy balance of annual and perennial lignocellulosic crops for bio-refinery use: a four-year field experiment in Belgium. European Journal of Agronomy, doi:10.1016/j.eja.2014.11.001.

Ngosong C, Gabriel E, Ruess L (2012) Use of the signature fatty acid 16:1 15 as a tool to determine the distribution of arbuscular mycorrhizal fungi in soil. Journal of Lipids, 236807, doi: 10.1155/2012/236807

Oksanen J, Blanchet FG, Kindt R et al. (2011) Vegan: Community Ecology Package. R package version 1.17-6. Available at: http://CRAN.R-project.org/package=vegan (accessed 25 February 2011).

Omonode RA, Vyn TJ (2006) Vertical distribution of soil organic carbon and nitrogen under warm-season native grasses relative to croplands in west-central Indiana, USA. Agriculture, Ecosystems \& Environment, 117, 159-170.

Oostenbrink M (1960) Estimating nematode populations by some selected methods. Nematology, 6, 85-102.

Pellegrino E, Di Bene C, Tozzini C, Bonari E (2011) Impact on soil quality of a 10year-old short-rotation coppice poplar stand compared with intensive agricultura and uncultivated systems in a Mediterranean area. Agriculture, Ecosystems \& Environment, 140, 245-254.

Poeplau C, Don A (2014) Soil carbon changes under Miscanthus driven by C4 accumulation and $\mathrm{C} 3$ decompostion - toward a default sequestration function. GCB Bioenergy, 6, 327-338.

Qin Z, Zhuang Q, Chen M (2012) Impacts of land use change due to biofuel crops on carbon balance, bioenergy production, and agricultural yield, in the conterminous United States. GCB Bioenergy, 4, 277-288.

Raaijmakers JM, Paulitz TC, Steinberg C, Alabouvette C, Moënne-Loccoz Y (2009) The rhizosphere: a playground and battlefield for soilborne pathogens and beneficial microorganisms. Plant and Soil, 321, 341-361.

Rooney DC, Killham K, Bending GD, Baggs E, Weih M, Hodge A (2009) Mycorrhizas and biomass crops: opportunities for future sustainable development. Trends in Plant Science, 14, 542-549.

Schaffers AP, Sýkora KV (2000) Reliability of Ellenberg indicator values for moisture, nitrogen and soil reaction: a comparison with field measurements. Journal of Vegetation Science, 11, 225-244.

Scharlemann JPW, Laurance WF (2008) How green are biofuels? Science, 319, 43-44

Schmidt SK, Lipson DA, Raab TK (2000) Effects of Willows (Salix brachycarpa) on populations of salicylate-mineralizing microorganisms in alpine soils. Journal of Chemical Ecology, 26, 2049-2057.

Searchinger T, Heimlich R, Houghton RA et al. (2008) Use of US croplands for biofuels increases greenhouse gases through emissions from land-use change. Science, 319, 1238-1240.

Siepel H (1996) Biodiversity of soil microarthropods: the filtering of species. Biodiversity \& Conservation, 5, 251-260.

Sierra M, Martínez FJ, Verde R, Martín FJ, Macías F (2013) Soil-carbon sequestration and soil-carbon fractions, comparison between poplar plantations and corn crops in south-eastern Spain. Soil and Tillage Research, 130, 1-6.

Six J, Elliott E, Paustian K, Doran J (1998) Aggregation and soil organic matter accumulation in cultivated and native grassland soils. Soil Science Society of America Journal, 62, 1367-1377.

Six J, Elliott E, Paustian K (1999) Aggregate and soil organic matter dynamics under conventional and no-tillage systems. Soil Science Society of America Journal, 63, 1350-1358

Six J, Elliott E, Paustian K (2000) Soil macroaggregate turnover and microaggregate formation: a mechanism for $\mathrm{C}$ sequestration under no-tillage agriculture. Soil Biology and Biochemistry, 32, 2099-2103.
Taghizadeh-Toosi A (2014) Changes in carbon stocks of Danish agricultural mineral soils during 1986-2009. European Journal of Soil Science, 65, 730-740.

The White House (2002) Global Climate Change Policy Book: A new Approach. The White House, Washington, DC.

Tilman D, Socolow R, Foley JA et al. (2009) Beneficial biofuels - the food, energy, and environment trilemma. Science, 325, 270.

Van Bruggen A (1995) Plant disease severity in high-input compared to reducedinput and organic farming systems. Plant Disease, 79, 976-984.

Van Bruggen A, Semenov A (2000) In search of biological indicators for soil health and disease suppression. Applied Soil Ecology, 15, 13-24.

Van Soest PJ, Robertson JB, Lewis BA (1991) Methods for dietary fiber, neutral detergent fiber, and nonstarch polysaccharides in relation to animal nutrition. Journal of Dairy Science, 74, 3583-3597.

VMM (2014) Verzurende en Vermestende Luchtverontreiniging in Vlaanderen (in Dutch). VMM, Brussels.

Von Fircks Y, Ericsson T, Sennerby-Forsse L (2001) Seasonal variation of macronutrients in leaves, stems and roots of Salix dasyclados Wimm. grown at two nutrient levels. Biomass and Bioenergy, 21, 321-334.

Workneh F, Van Bruggen A, Drinkwater L, Shennan C (1993) Variables associated with corky root and Phytophthora root rot of tomatoes in organic and conventional farms. Phytopathology, 83, 581-589.

Zan CS, Fyles JW, Girouard P, Samson RA (2001) Carbon sequestration in perennial bioenergy, annual corn and uncultivated systems in southern Quebec. Agriculture, Ecosystems \& Environment, 86, 135-144.

Zatta A, Clifton-Brown J, Robson P, Hastings A, Monti A (2014) Land use change from $\mathrm{C} 3$ grassland to $\mathrm{C} 4$ Miscanthus: effects on soil carbon content and estimated mitigation benefit after six years. GCB Bioenergy, 6, 360-370.

\section{Supporting Information}

Additional Supporting Information may be found in the online version of this article:

Table S1. Overview of measurements that were collected in each of the bioenergy crops.

Figure S1. Experimental field setup with position of all bioenergy crops.

Figure S2. (A) Soil $\mathrm{pH}_{\left(\mathrm{H}_{2} \mathrm{O}\right)}$ and (B) earthworm numbers in each of the different bioenergy crops in 2012.

Figure S3. Changes in nematode community composition A) Differences in $\mathrm{CP}$-values between different bioenergy crops.

Figure S4. AMF biomass (in $\mathrm{mg} / \mathrm{kg}$ dry soil) as calculated from NLFA 16:1 $\omega 5$ for four different bioenergy crops.

Figure S5. Average cover and average Ellenberg $\mathrm{N}$ value for understory plant communities in different bioenergy crops.

Figure S6. Belowground dry matter biomass of wheat plants (in grams) in the nutrient treatment (left) and control treatment (right) 